Meta

Journal des traducteurs

Translators' Journal

\title{
Dissenting Voices: When Paratexts Clash With Texts. Paratextual Intervention in Persian Translations of Texts Relating to the Iran-Iraq War
}

\section{Reza Yalsharzeh, Hossein Barati et Akbar Hesabi}

Volume 64, numéro 1, avril 2019

URI : https://id.erudit.org/iderudit/1065330ar

DOI : https://doi.org/10.7202/1065330ar

Aller au sommaire du numéro

Éditeur(s)

Les Presses de l’Université de Montréal

ISSN

0026-0452 (imprimé)

1492-1421 (numérique)

Découvrir la revue

Citer cet article

Yalsharzeh, R., Barati, H. \& Hesabi, A. (2019). Dissenting Voices: When Paratexts Clash With Texts. Paratextual Intervention in Persian Translations of Texts Relating to the Iran-Iraq War. Meta, 64(1), 103-124.

https://doi.org/10.7202/1065330ar
Résumé de l'article

Cette étude utilise la théorie narrative et le concept de cadrage narratif, tels que développés par Somers et Gibson (1994) et Baker (2006), pour étudier la médiation paratextuelle et la présence discursive de différents agents dans des traductions persanes de textes politiques écrits par des auteurs anglo-américains sur la Guerre Iran-Irak. En explorant les récits dominants dans les paratextes et plus particulièrement dans les préfaces et les notes de bas de page des traductions persanes, cet article examine comment ceux-ci ont joué un rôle crucial dans le recadrage des récits des auteurs anglo-américains à travers le matériel paratextuel. À cette fin, les récits des paratextes ont été analysés à l'aide de quatre techniques de cadrage élaborées par Somers \& Gibson (1994) et Baker (2006), encadrées par la temporalité / spatialité, l'appropriation sélective, l'étiquetage et le positionnement des participants. L'analyse du matériel paratextuel montre qu'en dehors de leurs fonctions introductives et explicatives, les paratextes peuvent être considérés comme une sorte de métadiscours sur les traductions réelles. Le document conclut que les paratextes dans les traductions persanes sont utilisés de manière politique et idéologique pour guider les lecteurs de la langue cible et exprimer les interprétations appropriées pour les divers participants institutionnels impliqués dans le processus de traduction en Iran. 


\title{
Dissenting Voices: When Paratexts Clash With Texts. Paratextual Intervention in Persian Translations of Texts Relating to the Iran- Iraq War
}

\author{
REZA YALSHARZEH \\ University of Isfahan, Isfahan, Iran \\ reyalsharzeh@gmail.com
}

HOSSEIN BARATI

University of Isfahan, Isfahan, Iran

barati@fgn.ui.ac.ir

AKBAR HESABI

University of Isfahan, Isfahan, Iran

a.hesabi@fgn.ui.ac.ir

\section{RÉSUMÉ}

Cette étude utilise la théorie narrative et le concept de cadrage narratif, tels que développés par Somers et Gibson (1994) et Baker (2006), pour étudier la médiation paratextuelle et la présence discursive de différents agents dans des traductions persanes de textes politiques écrits par des auteurs anglo-américains sur la Guerre Iran-Irak. En explorant les récits dominants dans les paratextes et plus particulièrement dans les préfaces et les notes de bas de page des traductions persanes, cet article examine comment ceux-ci ont joué un rôle crucial dans le recadrage des récits des auteurs anglo-américains à travers le matériel paratextuel. À cette fin, les récits des paratextes ont été analysés à l'aide de quatre techniques de cadrage élaborées par Somers \& Gibson (1994) et Baker (2006), encadrées par la temporalité / spatialité, l'appropriation sélective, l'étiquetage et le positionnement des participants. L'analyse du matériel paratextuel montre qu'en dehors de leurs fonctions introductives et explicatives, les paratextes peuvent être considérés comme une sorte de métadiscours sur les traductions réelles. Le document conclut que les paratextes dans les traductions persanes sont utilisés de manière politique et idéologique pour guider les lecteurs de la langue cible et exprimer les interprétations appropriées pour les divers participants institutionnels impliqués dans le processus de traduction en Iran.

\section{ABSTRACT}

This study uses narrative theory and the concept of narrative framing, as elaborated by Somers and Gibson (1994) and Baker (2006), to study the paratextual mediation and discursive presence of different agents in Persian translations of political texts written by Western authors about the Iran-Iraq war. By exploring the narratives dominant in the paratexts, and more specifically in the prefaces and footnotes of Persian translations, this paper examines how these have played a crucial role in reframing the narratives of Western authors through paratextual material. To this end, the narratives in the paratexts have been analyzed using four framing techniques elaborated by Somers and Gibson (1994) and Baker (2006), which are framing by temporality/spatiality, selective appropriation, labeling and participant positioning. The analysis of paratextual material shows that, apart from their introductory and explanatory functions, paratexts can be viewed as a kind of metadiscourse on the actual translations. The paper concludes that paratexts 
in the Persian translations are used in political and ideological ways to guide target language readers and to express the appropriate interpretations, or deemed appropriate, by the various institutional participants involved in the translation process in Iran.

\section{RESUMEN}

Este estudio utiliza la teoría narrativa y el concepto de encuadre narrativo elaborado por Somers y Gibson (1994) y Baker (2006) para estudiar la mediación paratextual y la presencia discursiva de diferentes agentes en las traducciones persas de textos políticos escritos por autores angloamericanos sobre la Guerra Irán-Iraq. Al explorar las narrativas dominantes en los paratextos y más específicamente en los prefacios y notas al pie de página de las traducciones persas, este documento examina cómo estos han desempeñado un papel crucial en la reformulación de las narraciones de los autores angloamericanos a través de material paratextual. Con este fin, las narraciones en los paratextos se han analizado utilizando cuatro técnicas de enmarcado elaboradas por Somers y Gibson (1994) y Baker (2006), que están enmarcadas por la temporalidad / espacialidad, la apropiación selectiva, el etiquetado y el posicionamiento de los participantes. El análisis del material paratextual muestra que, aparte de sus funciones introductorias y explicativas, los paratextos se pueden ver como una especie de metadiscurso sobre las traducciones reales. El documento concluye que los paratextos en las traducciones persas se usan en formas políticas e ideológicas para guiar a los lectores del idioma meta y expresar las interpretaciones apropiadas para los diversos participantes institucionales involucrados en el proceso de traducción en Irán.

\section{MOTS CLÉS/ KEYWORDS/PALABRAS CLAVE}

temporalité / spatialité, appropriation sélective, étiquetage, positionnement des participants, paratexte

temporality / spatiality, selective appropriation, labeling, participant positioning, paratext temporalidad / espacialidad, apropiación selectiva, etiquetado, posicionamiento de participantes, paratexto

\section{Introduction}

The Iran-Iraq War was an armed conflict between Iran and Iraq, two neighboring countries, which lasted from September 1980 to August 1988. The war had devastating effects on the two countries, and resulted in many casualties and much destruction on both sides. There are several features, according to Hiro (1991), that make this war unique among modern day conflicts. First, it was the longest conventional war of the twentieth century and, unlike the Arab-Israeli and Indo-Pakistani hostilities, it was not a brief but intense encounter between the combatants. Moreover, unlike many post-Second World War conflicts, this war did not result in a sharp division between the two superpowers.

Chubin and Tripp argue that the war fought between the two countries was "less material or territorial than it [was] moral or ideological" (1988: 1). Similarly, Murray and Woods maintain that the two countries' "political and ideological views of the world made a major conflict between them inevitable" (2014: 35). Other scholars have also mentioned ideological clashes among the numerous factors that fed the war machine between the two countries. Joyner (1990), King and Karsh (2006), Donovan (2011), and Hooton, Cooper, et al. (2016) are among such scholars, just to name a few. As a result, the war gave rise to a number of opposing narratives in both countries as well as in the rest of the world, regarding different aspects of the conflict. 
Using narrative theory as its theoretical framework, this study focuses on the narratological analysis of the paratextual material - more specifically, the analysis of narratives that can be found in the prefaces and footnotes - of the Persian translations of six English books about the Iran-Iraq war, written by Western authors. These books were translated, then published by the Holy Defence Documentation Center ${ }^{1}$ (hereafter HDDC), a state-owned publishing house run by the Iranian army. This publishing house has put out many original books on the war and is in large part responsible for the construction and legitimization of narratives about the war that have had a wide circulation in the press and electronic media in the Islamic Republic of Iran. It should be pointed out that this publishing house is responsible for conducting research, collecting documents, as well as publishing and circulating works related to the war in Iran. The very name of the publishing house is motivated by an ideological and religious agenda, one that has given rise to two commonly used names for the war in Iran: the Imposed $W_{a r}^{2}$ and the Holy Defence. ${ }^{3}$ Indeed, in domestic narratives, it is believed that the war was imposed on Iran and that it was necessary not only to defend the country, but also Islam.

Therefore, we asked the following questions. How are the texts, written by Western authors, presented to the Iranian readership, who is steeped in totally different narratives about the war? How are the translations framed for the target language readership by translators, the publisher, editors, and other agents involved in the translation process? Likewise, this study attempts to find out how paratext is used in the translations of the works most critical of the dominant narratives in Iran.

\section{Narrative theory and translation}

Narrative is a key concept in the humanities, one that can be defined and approached in various ways in different fields. According to Meretoja (2014), there are generally two main approaches to narrative. Some theorists like Hayden White, Louis Mink, and Daniel Dennett consider narrative primarily as a cognitive instrument for imposing meaningful order onto human life and experience. For instance, Mink maintains that "stories are not lived but told, since 'life' in itself has no beginnings, middles or ends" (1970: 557). These theorists adopt a particular epistemological stance regarding narrative. To them, the ordering of events and the nature of relationships between them are of prime importance. However, other scholars like Paul Ricœur, Charles Taylor, and Alasdair Macintyre see narrative as an ontological activity that characterizes the human way of being in the world, that is, something essential for humans. These scholars have an ontological view of narrative.

Similarly, in social and communication theory, according to Somers (1997) and Somers and Gibson (1994), narrative is the essential mode by which human beings experience the world. According to them "everything we know is the result of numerous cross-cutting story lines in which social actors locate themselves" (Somers and Gibson 1994: 41). They also maintain that "social life is itself storied and narrative is an ontological condition of social life" (1994: 38). However, from a socio-pragmatic and literary point of view, narrative is regarded as one of several modes of communication, as compared to argumentation, for instance.

In her description of narrative, Baker maintains that narratives are "public and personal stories that we subscribe to and that guide our behavior" (2006: 19). 
Furthermore, she maintains that "narrative is the principal and inescapable mode by which we experience the world. These stories are constructed- not discovered - by us in the course of making sense of the reality" (2006: 169).

According to Baker (2006), translation and interpreting are necessary for justifying, legitimizing, and circulating the narratives that form the intellectual and moral environment for various events in the world. Baker argues that translators and interpreters play an undeniable role in "both disseminating and contesting public narratives within and across national boundaries" (2006: 5). Elsewhere, she mentions the significance of publishers, editors, and other agents involved in the translation process, who can "accentuate, undermine or modify aspects of the narrative encoded in the source text or utterance and in doing so participate in shaping social reality" (2006: 5).

Following Baker's (2006) initial work on the application of narrative theory in translation studies, a number of studies have attempted to apply narrative theory to translation. Harding $(2009,2012)$ relied on it for the textual analysis of online media reportages on the Russian hostage crisis in September 2004. She concluded that translation has a vast impact on the construction of narratives. In another study, Baldo (2008) considered translation as re-narration in Canadian-Italian writing and analyzed how code-switching between English and Italian among Italian immigrants in Canada has been dealt with in translations. Ayoub (2010) investigated the rewriting of children's literature in Arabic translations, focusing on paratextual devices like the title, cover pages, illustrations, and other paratextual elements. In a like manner, Al-Herthani (2009), focusing on paratextual analysis, analyzed the translations of Edward Said's works into Arabic and their re-narrations by different Arab institutions.

Viewing narratives as stories that can produce, reproduce, and also contest existing power structures, this study attempts to show how a historical event like the Iran-Iraq war is interpreted and narrated in totally different ways by Iranian and Western authors, and how different agents in the translation process make use of paratext, a "privileged place" in Genette's (1987/1997: 2) terms. These agents reframe the dominant narratives in the source texts and thus guide the readers of the translations in their interpretation of the text.

This study makes use of Baker's (2006) four key framing strategies to analyze the discordant narratives in the source and target texts. These strategies are: temporal and spatial framing, framing through selective appropriation, framing by labeling, and repositioning of participants. Framing, according to Baker, is an "active process of signification by means of which we constantly participate in the construction of reality" (2006: 167). These framing strategies will be explained and exemplified in more detail in Section 5.

\section{Paratext and translation}

Paratexts are defined by Genette as:

[...] those liminal devices and conversations, both within the book (peritext) and outside it (epitext) that mediate the book to the reader: titles and subtitles, pseudonym, forewords, dedications, epigraphs, prefaces, intertitles, notes, epilogues and afterwards. (1987/1997: xviii) 
Elsewhere in his work, Genette argues that these liminal devices participate in the complex mediation taking place between book, author, publisher, and reader of the book.

Genette considers paratext "a zone not only of transition but also of transaction" (1987/1997: 2). By “zone of transaction," Genette means that paratext is a:

[...] privileged place of a pragmatics and a strategy, of an influence on the public, an influence that- whether well or poorly understood and achieved - is at the service of better reception for the text and a more pertinent reading of it in the eyes of the author and its allies. (Genette 1987/1997: 2)

According to Genette (1987/1997), "functionality" is the most essential property of paratext. He believes that paratexts always fulfill a function and they can influence the way readers approach a given text.

According to Gil-Bardaji, Orero, et al. (2012), the notion of paratext has been far less investigated in translation studies than in the rest of the humanities. A few noteworthy studies are Kovala (1996), Watts (2000), Tahir Gürçağlar (2002), Harvey (2003), Gil-Bardaji (2009), and Roberts (2010). Still fewer studies have investigated the paratextual mediation of different agents in the translation process using narrative theory. These studies are Ayoub (2010), Summers (2013), Dubbati and Abudayeh (2017), and Kim (2017) - which focus on literary translation -, and Hijjo and Kaur (2017), with a focus on media translation. This motivates the need to conduct a study with a focus on the translation of political texts.

\section{Points of contention}

The corpus of the present study consists of six books written in English by Western authors, on the subject of the Iran-Iraq War. All have been translated into Persian by the state-owned HDDC in the Islamic Republic of Iran. Although these translations are published by the same publishing house, they were produced by different translators. The translations are accompanied by lengthy prefaces and numerous footnotes, authored either by the publisher or other agents affiliated with it, such as veterans of the war.

The publisher uses the paratextual spaces of the translations not only to reject the Western source authors' narratives about the war, but also to accentuate, restate, and justify its own narratives on the subject. Although the publisher disagrees with many of the source text narratives, it decided to translate the books nonetheless, to "familiarize the researchers and commanders of the war with the useful ideas of the books which are necessary for them to be aware of"4 (HDDC 2008: 21). An investigation of the prefaces and footnotes of the different Persian translations reveals that they convey similar narratives. In the prefaces and footnotes, the publisher reacted against all the narratives that are not in agreement with those dominant in Iran. It should be mentioned that the various narratives about the Iran-Iraq war fall into the category of "public" narratives, since they have been elaborated by official, social, and institutional organisations, and they are widely circulated by the press and electronic media. In other words, though not necessarily top-down in all cases, they are shared or collective narratives within Iranian society, ones that are widely advocated and advertised by the government. The books analyzed are: ${ }^{5}$ 
1. The Iran-Iraq War and the First Gulf War (2006) by Ralph King and Efraim Karsh;

2. The Longest War: the Iran-Iraq Military Conflict (1991) by Dilip Hiro;

3. A Poisonous Affair: America, Iraq and the Gassing of Halabja (2007) by Joost R. Hiltermann;

4. Tankers War: the Assault on Merchant Shipping during the Iran-Iraq War (1996) by Martin S. Navias and Edward R. Hooton;

5. The Lessons of Modern War. Vol. 2. The Iran-Iraq War (1990) by Anthony H. Cordesman and Abraham Wagner;

6. The Persian Gulf War: Lessons for Strategy, Law and Diplomacy (1990) by Christopher C. Joyner.

Efraim Karsh is an Israeli-British historian and emeritus professor of Middle East and Mediterranean Studies at King's College London, where he also acted as founding director of the Institute of Middle Eastern Studies. Dilip Hiro is a BritishPakistani author, journalist, and commentator who specializes in the politics of the Middle East and South Asia. Joost R. Hiltermann is Program Director of the International Crisis Group for the Middle East and North Africa, in Brussels. Martin S. Navias is a former lecturer in the Department of War Studies at King's College London. Edward R. Hooton is a defence writer, who has published numerous articles on military history. Anthony $\mathrm{H}$. Cordesman is an American national security analyst focussing on a number of global conflicts. Abraham R. Wagner is a senior research fellow at the Saltzman Institute of War and Peace Studies. Christopher C. Joyner was a professor of Government and Foreign Service at Georgetown University and the founder of the Institute for International Law and Politics (now, the Institute for Law, Science and Global Security). The Persian translations ${ }^{6}$ are as follows:

1. جنى ايران و عراق: بِيامد هاى سياسى- تحليل نظامى [Jang-e-Iran va Iraq: payamadhaye siasi- tahlil-e nezami] (2008; 1387 AH), translated by Sayed Saadat Hosseini Damabi;

2. طولانى ترين جنگ: رويارويى نظامى ايران و عراق (Tulanitarin jang: ruyaruii nezamie Iran va Iraq] (2011; 1391 AH), translated by Alireza Farshchi, Reza Faridzadeh, and Saeed Kafi;

3. رابطه زهرآكين: آمريكا-عراق و بمباران شيمبايى حلبجه [Rabeteye zahraghin: America, Iraq va bombarane shimiaii Halabjeh] (2013; 1392 AH), translated by Yaghoob Nemati;

4. جنح نفتكش ها: حمله به كثتيرانى تجارى در جنح ايران و عراق [Jang-e- naftkeshha: hamle be keshtiranie tejari dar jang-e- Iran va Iraq] (2013; 1392 AH), translated by Pejman Poorjabari and Rahmat Ghareh;

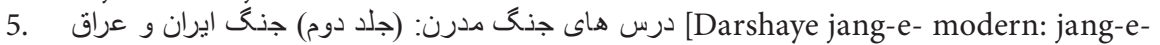
Iran va Iraq] (2011; 1390 AH), translated by Hossein Yekta;

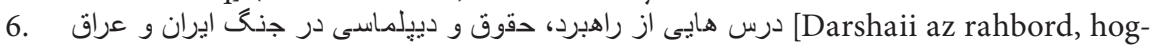
hogh va diplomacy dar jang-e- Iran va Iraq] (2011; 1390 AH), translated by Davood Olamaii.

As mentioned earlier, since all of the translations are from the same publishing house, similar narratives and sets of beliefs are found in all their prefaces and footnotes. These paratextual elements are used to argue several points. First, it is claimed that the Western source authors, who are affiliated with governments that sided with Iraq during the war, have either received false information or have manipulated the facts to suit their ends. Second, it is stated that Western countries are hostile to Iran and its Islamic Revolution. Thus, they encouraged Iraq to attack Iran in order 
to overthrow the new Iranian revolutionary government. Third, the different paratextual elements suggest that the source authors were biased and that they approached the issue with prejudice. Fourth, it is emphasized that one of the source authors is originally from Israel, a country considered hostile to Iran. Fifth, the authors' lack of firsthand information about the war zones is pointed out as a factor that led them astray and caused them to falsely present different aspects of the war to their readers. Sixth, it is said that the source authors overlook the role Western superpowers played in equipping Iraq with weapons of mass destruction and in imposing sanctions on Iran. Seventh, the source authors allegedly turned a blind eye to the "morale of martyrdom"7 (HDDC 2008: 16) and the "peoples' sacrifices"8 (HDDC 2011: 26), which are identified as some of the main reasons for Iran's military success. Finally, it is asserted that the source authors purposefully accused Iran of using countervalue and preemptive attacks against Iraqi cities in order to exonerate Iraq of any blame.

In summary, the points of contention that contribute to the discordant narratives about the war are as follows:

1. The reasons for the war;

2. The reasons for the rejection of Iraq's peace proposal;

3. The reactions of non-Arab states, for example the case of Israel;

4. The reason for Iraq's initial cessation of offensives;

5. The success of the operations conducted by the Revolutionary Guards;

6. The use of chemical weapons;

7. Iran's success in the first battle of al-Faw, a peninsula in southeast Iraq;

8. Countervalue escalation and strategic bombing.

In the following section, each narrative and the corresponding framing strategy are elaborated in detail.

\section{Types of framing and their use in narratives about the Iran-Iraq War}

\subsection{Spatial/Temporal framing}

According to Baker (2006), narratives are temporally and spatially embedded: they are always told in a particular time and place. Meanings are thus derived from the temporal moment and physical site of narratives. The very fact that the books were translated in Iran, in the context of many longstanding narratives and sets of beliefs in Iranian society, and that lengthy prefaces accompany the translations, ultimately affects the readers' interpretation of the Western narratives in the body of the translated works. Anti-Western narratives about the war are deeply ingrained in Iranian readers and have shaped their understanding of it. Upon encountering foreign narratives, readers are likely to compare them to the already established domestic ones. This can influence their interpretation of the translations. Moreover, in the paratextual material, the publisher emphatically rejects Western narratives about the war and reiterates those that are already prevalent and widely circulated within Iran, through various forms of common media, such as news and government reports, books, television, movies, etc. By doing so, the publisher emphasizes the trustworthiness of its own narratives. All of this results in a constant reaffirming of expected perspectives on the war, through paratextual material. 
The element of time is also relevant to the Iranian war context, since most of the translations were produced almost two decades after the war had ended. In the interim, different institutions and authorities, especially the HDDC, have constructed, elaborated, and circulated many narratives about the war. Having been embedded and socialized into the narratives that have been widely circulated in the press and media for so many years in Iran, the target text readers are likely to be influenced by the lengthy prefaces that frame the translations. These voluminous prefaces and introductions, which vary in length between two to sixteen pages, are intended to remind the readers of the deeply rooted domestic narratives about the war and to make the reading process familiar and effortless.

\subsection{Selective appropriation}

According to Baker (2006: 114), "[s]elective appropriation is found in patterns of omission and addition designed to suppress, accentuate or elaborate particular aspects of narrative". In the translations under study, this is achieved in the paratext, where source text narratives that are in conflict with domestic ones are reframed. This shows that paratexts can play an important role in the circulation of domestic narratives in a society. Below are some examples of these conflicting narratives about the war. Narratives in the source texts are described first, followed by an analysis of the publisher's reactions in the prefaces and footnotes (translations into English are provided).

\subsubsection{The reasons for the war}

According to the Western narratives, there are a number of causes for the Iran-Iraq war. King and Karsh (2006), for one, argue that "Iran's growing stridency" (p. 7) following the revolution and its intention to attack a "certain Arab country" (p. 8) caused the war between the two countries. Also, in the authors' opinion, Iran's intention to "alter the political status quo" (p. 7) in the region and "the split between Sunni and Shiite Muslims" (p. 5) are among the main reasons for the war.

\section{1) SOURCE TEXT}

It was Iran's growing stridency and its real and perceived ambition to alter the political status quo throughout the gulf -and particularly in Iraq- which led the government of Iraq to the belief that the use of force was necessary. (p. 7)

Most commentators have included among the causes of the war a general category of historical animosity, based on the old Arab-Persian ethnic and cultural rivalries and the split between Sunni and Shiite Muslims. (p. 5)

Iranian leaders declared themselves ready for war against "a certain Arab country". (p. 8)

(King and Karsh 2006: 5, 7-8)

PARATEXT (preface)

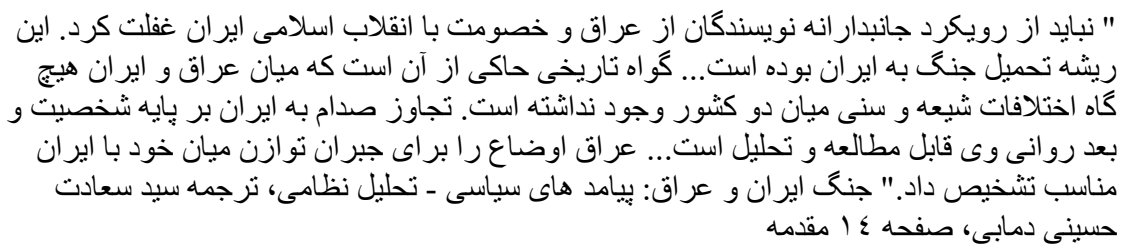


[We should not ignore the authors' biased approach in favor of Iraq and their hostility to the Islamic Revolution. This has been the main reason for imposing the war on Iran. The historical evidence suggests that there has never been Sunni and Shiite rivalries between the two countries. Saddam's invasion of Iran could be explained by an analysis of his character from a psychological perspective. Iraq also seized the opportunity to compensate the balance of power with Iran in the region. $]^{9}$

(HDDC 2008: 14; in King and Karsh 2006/2008)

Here, paratextual narratives are used to put forward alternative triggering factors for the war, which reframes and mediates the narratives about the "cause of the war" conveyed in the source text. The publisher argues that Western countries' animosity towards the Islamic Revolution, Iraq's intention to compensate the balance of power in the region, and Saddam's psychological character are some more compelling reasons for the war.

As can be seen, the same historical event has given rise to conflicting narratives about the reasons for the war. In other words, the Iranian publisher and the Western authors propose different narratives about the same event. The paratextual materials of the Persian translations are used to reframe the Western narratives by the selective appropriation of events that led to the war.

\subsubsection{Iran's rejection of peace proposals}

Hiltermann argues that Iraq's repeated pleas for peace were rejected by Iran, because of the latter's supposed intention to overthrow the Iraqi regime by supporting Iraqi Shiites. He writes:

\section{2) SOURCE TEXT}

Iraq's highest decision-making organs offered to withdraw their forces to the international border and renege on all territorial claims. Flush with victory guided by a sense of revenge and perhaps seeing an opportunity to spread the revolution to Iraq's majority Shiite population and thus bringing the collapse of the Iraqi regime, the clerics decided to press for the advantage.

(Hiltermann 2007: 24)

PARATEXT (footnote)

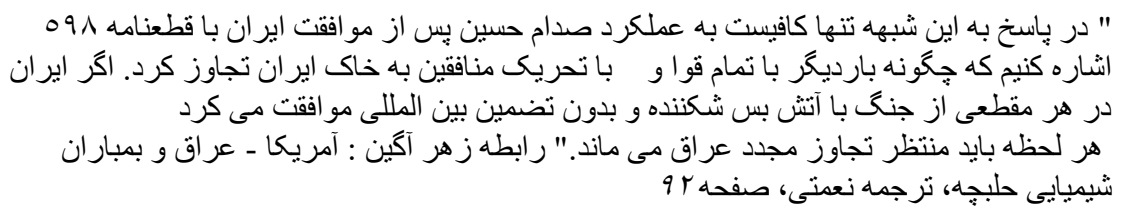

[To respond to this position, it suffices to note Saddam's actions after Iran's acceptance of resolution 598 [which was about the ceasefire] given that he reinvaded Iranian borders with full force with the collaboration of Monafeghins. At any stage of the war, had Iran agreed to any fragile ceasefire, not internationally guaranteed, it should have awaited Iraq's renewed attacks any time.]

(HDDC 2013a: 92; in Hiltermann 2007/2013)

As can be seen, an opposing narrative about the rejection of a ceasefire by Iran is expressed in this footnote. The publisher argues that the peace proposal was temporary and not internationally guaranteed. Furthermore, it brings up the Iraqi 
offensive that followed ceasefire resolution 598, which should explain Iran's distrust of the Iraqi leadership. It also asserts that Iran had no guarantees that Iraq would not reattack after the ceasefire.

As is evident, paratextual elements play an undeniable role in the publishers attempts to resist the source narratives that challenge the intellectual and moral background of the war in Iran. By selective appropriation of particular events, paratexts explain, justify, and legitimize the public narratives that are widely common in Iran and by so doing provide a means of contesting Western narratives about the war.

\subsubsection{The reactions of non-Arab states: the case of Israel}

In the Western narratives, it is said that Israel was one of Iran's main weapon suppliers during the war. As Joyner writes:

3) SOURCE TEXT

Shipments of arms in support of the Reagan initiative with Iran began in the summer of 1985 and continued until the fall of 1986 . Some of the early shipments in 1985 were made by Israel acting on behalf of the United States, which apparently replenished Israeli stock.

(Joyner 1990: 79)

PARATEXT (footnote)

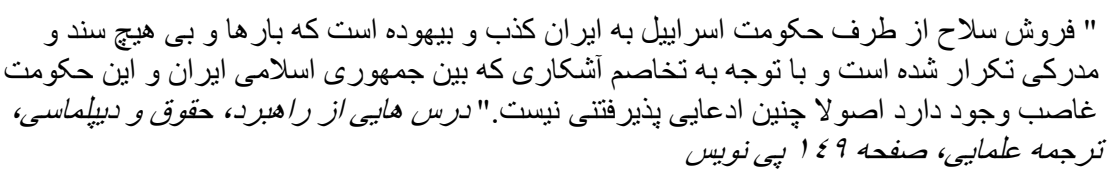

[Israel's selling of arms to Iran is a false claim and there is no evidence for it. Given the hostilities between Iran and this usurping regime, such a claim is unacceptable.]

(HDDC 2011f: 149; in Joyner 1990/2011)

In the Persian translation of Joyner's book, the aforementioned footnote conveys a narrative in which any relationship between Iran and Israel is vehemently denied. The publisher counters that the Iranian government has no relations with Israel whatsoever and that such a relationship is impossible due to Israel's hostility towards the Islamic Revolution in Iran.

By means of the paratexts, different agents (publisher, editors, etc.) thus highlight particular facts in order to reframe the source narrative.

\subsubsection{The reason for Iraq's initial cessation of offensives}

According to King and Karsh (2006), the reason for Iraq's initial halting of offensives was due to its "modest objectives" and "self-imposed restraint."

4) SOURCE TEXT

It was not the fervor of the Pasdaran that halted Iraq's initial offensive but rather Iraq's self-imposed restraint. The Iraqi forces had secured their initial objectives. But those objectives may have been too modest. 
PARATEXT (preface)

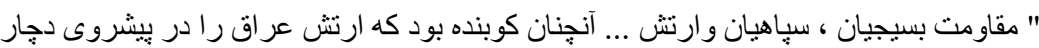

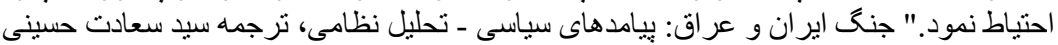

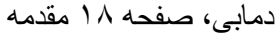

[The resistance of [Iranian] military and paramilitary forces [...] was so crushing that it made the Iraqi army more hesitant in its progress.]

(HDDC 2008: 18; in King and Karsh 2006/2008)

As expected, in the paratext some other reasons are given for the cessation of operations by Iraq in the first few weeks of the war. Indeed, the preface identifies "the crushing resistance of Iranian forces" as the main reason for the cessation of hostilities.

Once again, the two sides agree on the same fact, that is, Iraq's aborted offensive, but disagree completely on how to interpret it and how to relate the events to each other. In the paratexts, the explanations which are in line with the dominant narratives in Iran are emphasized.

\subsubsection{The success of the operations conducted by the Revolutionary Guards}

According to Hiro (1991), successful Iranian offensives in Iraq were led by "professional soldiers" rather that the Revolutionary Guards, who allegedly lacked leadership and organization.

5) SOURCE TEXT

On the battlefield Iran's revolutionary guards proved more vulnerable to enemy ambushes than professional soldiers. Owing to poor leadership and insufficient experience the guards failed to time precisely their infantry attacks.

(Hiro 1991: 88)

\section{PARATEXTS}

Footnote

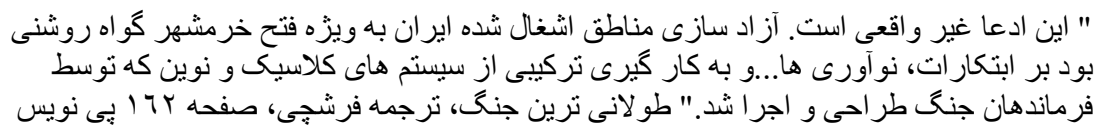

[This claim is baseless. The liberation of Iranian occupied territories, namely Khorramshahr, demonstrates the creativity, innovations, [...] and the hybrid use of classic and novel methods designed and implemented by commanders.]

(HDDC 2011d: 162; in Hiro 1991/2011)

Preface

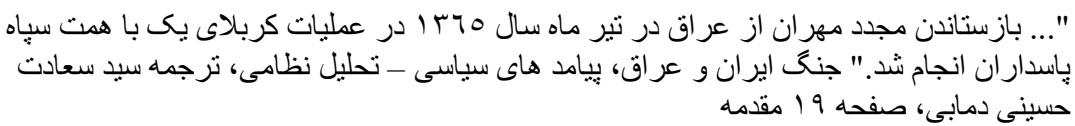

[[...] The liberation of Mehran [an Iranian town] from the Iraqi army in Tir 1365 AH [June 1986] was carried out in the Karbala 1 Operation by the Revolutionary Guards].

(HDDC 2008: 19; in King and Karsh 2006/2008) 
In the Persian translation of the book, a footnote is added to contradict Hiro's assertion. Indeed, according to Iranian narratives, the success of operations carried out by the Revolutionary Guards was evident. In support of this claim, the footnote alludes to the liberation of Khorramshahr, which was the result of a collaboration between the Revolutionary Guards and the army. In the preface of another translation, the publisher refers to the liberation of Mehran, achieved by the Revolutionary Guards, which constitutes another clear piece of evidence for their experience and success.

Once again, paratextual elements are used as a tool of discursive resistance to the Western narratives about the war.

\subsubsection{Use of chemical weapons}

Cordesman and Wagner (1990) assert that the use of chemical weapons was extensive during the war. They do not point to a particular perpetrator, implying that both belligerent countries resorted to poison gas.

6) SOURCE TEXT

The war escalated to involve Western naval forces, long-range surface-to-surface missiles, and the extensive use of poison gas.

(Cordesman and Wagner 1990: 1)

PARATEXT (footnote)

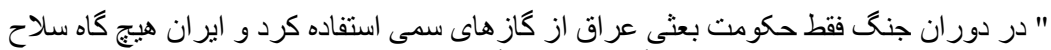

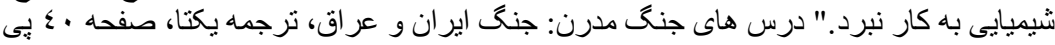

[During the war only Iraq used poisonous gases and Iran never used chemical weapons.]

(HDDC 2011b: 40; in Cordesman and Wagner 1990/2011)

In a footnote, the publisher places the responsibility for any chemical attacks solely on Iraq. This focuses the readers' attention on the opposing country and its alleged use of chemical weapons, thus steering them to view the chemical attacks differently from the Western perspective.

\subsubsection{Iran's success in the first battle of al-Faw}

For Hiltermann (2007), Iran's success in the battle of al-Faw was due to the use of "Tow and Hawk missiles" bought from foreign countries before the battle.

\section{7) SOURCE TEXT}

Iran received 2008 TOW missiles and 235 Hawks and it deployed them as soon as shipments started arriving in 1985 - with immediate results. In hindsight, therefore, the defeat at Faw was painful not only because of the slap to Iraqi pride [...].

(Hiltermann 2007: 77) 
PARATEXTS

Footnote

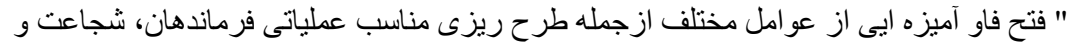

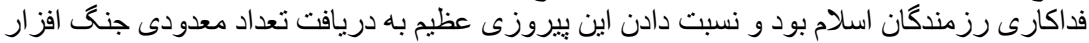

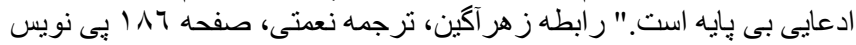

[The conquest of Faw was the result of a number of factors such as the proper operational planning of the commanders as well as the courage and the sacrifices of the warriors of Islam [the Iranian soldiers]; attributing it to some limited number of weaponry is a baseless claim.]

(HDDC 2013a: 186; in Hiltermann 2007/2012)

Preface

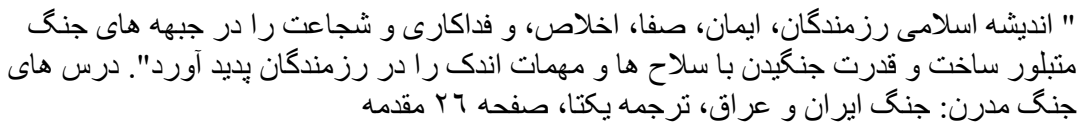

[The warriors' Islamic ideology manifested faith, purity, sincerity, sacrifice, and courage in the battlefields and enabled them to fight with a small amount of arms and ammunition.]

(HDDC 2011a: 26; in Cordesman and Wagner 1990/2011)

In the translation to Hiltermann book, the publisher uses a footnote to attribute Iran's success in the battle to the "courage" and "sacrifice of the warriors of Islam", among other factors. It would thus be misleading to explain the conquest of al-Faw by weaponry, as Iraq had similar missiles at its disposal during the war. In the preface to another translated book, the publisher again alludes to the courage, sacrifice, purity, etc. of the "warriors." As these examples show, in the Iranian context, factors such as "courage" and "sacrifice" on the battlefield are held in great esteem. Therefore, in the paratextual materials, victory on the battlefield, in general, and the victory at al-Faw, in particular, are attributed to human efforts rather than warfare. The very fact that the publisher explicitly emphasizes factors such courage and sacrifice, mentioning other factors only implicitly, is itself a discursive and ideological act that attempts to intellectually frame the war. In the end, by attributing the success of the battle to different causes, the publisher tries to reframe the source text narrative and to guide the readers in their interpretation of the events.

\subsubsection{Countervalue escalation and strategic bombing}

According to Navias and Hooton (1996), Iraq's attacks on Iranian cities were only a reprisal against Iran's refusal to give an undertaking not to attack Iraqi cities.

8) SOURCE TEXT

In February Saddam ordered air and missile attacks upon Iranian population centers following Tehran's refusal to give an undertaking not to attack Iraqi towns or cities.

(Navias and Hooton 1996: 71) 


\section{PARATEXTS}

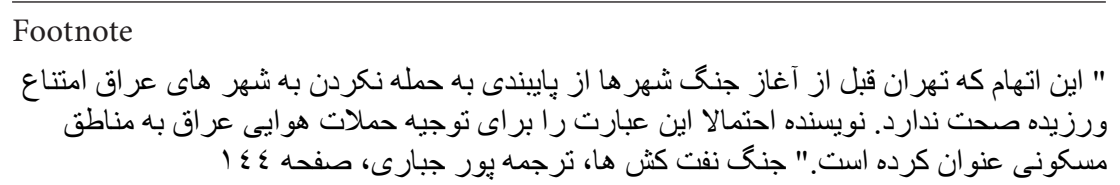

[The claim that Iran had not committed to refraining from attacks on cities, prior to the onset of the city war, is not true. Perhaps, the author has included this in order to justify Iraqi air strikes on residential areas.]

(HDDC 2013c: 144; in Navias and Hooton 1996/2013)

Preface

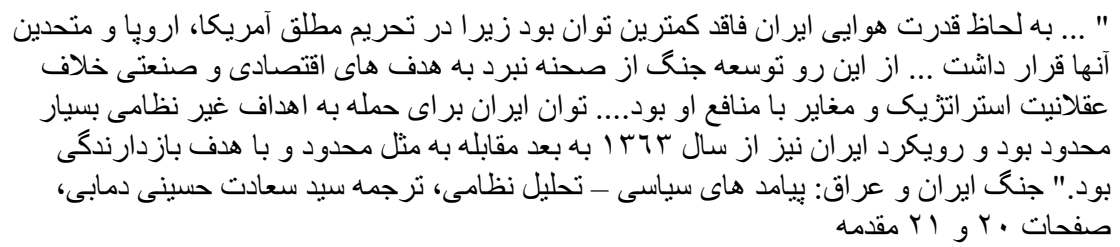

[In respect to the air force, Iran lacked even the basic capabilities, since it was under very stringent sanctions by America, Europe and their allies [...] Therefore, the expansion of the war from the war zones to economic and industrial targets was against strategic rationality and contrary to Iran's interests [...] Iran's power to attack non-military targets was very limited and its position from $1363 \mathrm{AH}$ [1984] was based on limited confrontation aimed at deterrence.]

(HDDC 2008: 20-21; in King and Karsh 2006/2008)

In the narrative that the publisher wishes to convey, Iraq is the main party responsible for the city war. This narrative is expressed in a footnote to the translation of Navias and Hooton's book, but also in the preface of another translated book (King and Karsh 2006/2008; see above). In the latter, arguments in favour of the domestic narrative is given, namely that Iran did not possess an air force powerful enough to launch and continue attacks on Iraqi cities.

\subsubsection{Summary}

As the above examples show, paratextual elements are important sites of institutional framing in the translation process. Studying translations in general and paratexts in particular is very useful to reveal the ideological stance of the institutions which play active roles in the translation process. These examples also indicate that paratextual space is a locus of tension and clash between competing narratives, where, in this case, trust in the foreign narratives is continually discouraged. The monolingual nature of paratextual material disturbs the balance of power in favor of target text narratives, which can influence the reception of the translations among the target readership. Like translation, paratextual authorship is a process "fraught with obstacles and tensions," to use Brisset's terms (1990/1996: 6). However, if this tension leads to a clash, the foreign narratives will often fight a losing battle. Paratext is an exemplary of the trial of the foreign. 


\subsection{Labeling}

According to Baker, "the use of lexical item, term, or phrase to identify a person, place, event or other important events of a narrative is considered labeling" (2006: 168). The peritexts of the translations in this study use labels to refer to the source text authors, to the works themselves and to source narratives. In some parts of the prefaces, the authors are referred to by their nationalities. It is stated in the prefaces, that due to factors such as the ethnocentric perspective of European, American, and Israeli authors, and also to their lack of information and understanding of the nature and details of the battle zones, their works are of less value and are more journalistic in nature. Two paratextual examples are found in Hosseini's (King and Karsh 2006/2008), as well as Poorjabari and Ghareh's (Navias and Hooton 1996/2013) translations. In Hosseini's translation, the publisher states in the preface that " $\mathrm{r}]$ egardless of the ethnocentric perspective of the European, American and especially Israeli authors such as Efraim Karsh, their works are of less value because of the authors' incomplete knowledge and lack of understanding of the nature and details of the battle zones"10 (HDDC 2008: 14). In the preface of Poorjabari and Ghareh's translation, the publisher describes some of the source narratives as "contrary to the historical facts, incomplete, and biased"11 (HDDC 2013b: 10) and they thus necessitate "the addition of some explanations in the footnote or the body of the text"12 (HDDC 2013b: 11). Elsewhere, in the preface to Hosseini's translation, it is mentioned that "because of their affiliation with the foreign countries which supported Iraq and their incomplete information, the authors went astray and manipulated the facts"13 (HDDC 2008: 11).

Labeling is explicitly addressed in the paratexts under study, as the publisher and editors use them to explain and justify the lexical choices made in the translations. For instance, the publisher (HDDC 2011f: 25) explains in a footnote ${ }^{14}$ the reason behind rendering the word Gulf into Khalije Fars [Gulf Persian] ${ }^{15}$ throughout Olamaii's translation (Joyner 1990/2011). Similarly, in the paratexts, the source text authors' use of some terms is contested. As an example, the publisher challenges Cordesman and Wagner's use of the word departure in the phrase: "Shah's departure from power" (1990: 11) as a wrong word choice. The word farar [flight] ${ }^{16}$ is suggested instead of khorooj [departure] ${ }^{17}$ to render the English departure in a footnote (HDDC 2011b: 56) in Yekta's translation (Cordesman and Wagner 1990/2011).

\subsection{Positioning}

By "positioning" Baker means "the way in which participants in any interaction are positioned, or position themselves, in relation to each other and to those outside the immediate event" (2006: 132). This technique is adopted in the paratextual material of the Persian translations as a means to establish trust with the intended reader. It allows the Persian translations to be positioned in a way that makes them more relevant to the target readers. Positioning is used for different purposes: to show the credibility of the established Iranian narratives and to show the legitimacy of the publisher, as an organization that was directly involved in the war, to publish these translations. To lend credibility to the dominant Iranian narratives, the publisher accentuates the source text narratives that are in line with existing Iranian narratives. By doing so, the publisher implies that foreign authors acknowledge some of the 
narratives that are current in Iran. This fact can give more currency to the domestic narratives about the war, given that even Western authors admit their accuracy. Paratextual material can thus be used to ensure the readers' trust in the domestic narratives and to position them in such a way as to accept those narratives more easily.

\subsubsection{Credibility}

By highlighting those narratives in the source texts that agree with the dominant Iranian narratives about the war in Iran, the publisher reassures the readers of their credibility and trustworthiness. This study makes obvious the important role played by paratexts in this process. Accentuating some narratives in the source texts which are in line with the Iranian narratives, such as Iraq's chemical attacks on Iran or the United States' support of Iraq during the war, helps the publisher to establish the authenticity of these domestic narratives. For instance, the publisher's preface in Yekta's translation (Cordesman and Wagner 1990/2011) states: “Iraq's use of chemical weapons against Iran is mentioned in this book"18 (HDDC 2011a: 31). Elsewhere, in the preface to Olamaii's translation (Joyner 1990/2011), the publisher states: “The United States' role in stimulating Iraq to attack Iran and standing up for Iraq during the war is evident throughout the book"19 (HDDC 2011e: 18). Finally, in the preface to Farshchi, Faridzahed, and Kafi's translation (Hiro 1991/2011), it is written that "the role of superpowers in supporting Iraq in all phases of the war is clearly mentioned in this book"20 (HDDC 2011c: 11).

\subsubsection{Uniqueness of the publications}

Translating foreign works about the Iran-Iraq war is a new project pursued by the Iranian publisher. It is referred to as jang az negahe digharan [war from others' perspective ${ }^{21}$ (HDDC 2008: 11) and gives the publisher a sense of uniqueness. The reason is that the translations within the project contain many new and unheard views about the war, which are likely to be interesting to Iranian readers. Another paratextual example can be found in Yekta's translation (Cordesman and Wagner 1990/2011). The publisher's preface states: “This book can familiarize the readers with the ideas of foreign military experts on the imposed war. Better understanding of the events and developments of the war requires its investigation from different perspectives"22 (HDDC 2011a: 36). Moreover, a sense of authenticity is conferred upon the publisher, as it is affiliated with veterans of the war, who experienced it firsthand and who now preface some translations. Also, the fact that the translated books are produced by a publishing house run by the army can give them a sense of authority and uniqueness. Indeed, HDDC is responsible for doing research on the war, and its various employees and affiliates had immediate contact with the war zones. All these factors are likely to influence the reception of the translations in Iran.

\section{Conclusion}

Translation can never be separated from ideological considerations and is always a socially-situated and culturally-embedded activity. Dominant discursive voices in a given society influence translation activity to a large extent. The most obvious example of this is the translators' and/or publishers' manipulative intrusions into 
actual translation products. Apart from this, translation agents can use "privileged spaces" (Genette 1987/1997: 2), spaces other than the core text, for their ideological investment.

These spaces include paratextual elements like prefaces, introductions, and footnotes, where ideologically significant and politically powerful material can be located. The study shows how paratexts can become vehicles for the expression of ideology. Therefore, they are powerful tools in the appropriation of the reading process.

This study shows that paratexts are not marginal or peripheral products with merely introductory functions, but powerful ideological instruments that have a fundamental epistemological dimension. Not only do the paratexts described here reflect the existing ideological and narratological structures about the war, but also they reproduce them.

The study also shows that paratexts are not "mere texts," but "a second opportunity" to reject Western narratives about the war and at the same time to explain, justify, and circulate their own counter-narratives. Prefaces and footnotes from the translations investigated in the present study convey numerous narratives that stand in stark opposition to those in the source texts. The "illocutionary force" of the paratextual materials, which clearly shows the potential of these texts, demonstrates how paratexts constitute crucial means of mediating and sustaining the domestic narratives about the war in Iranian society.

The voluminous prefaces authored by the publisher show how paratextual authorship functions as an active process of signification, by which it participates in the construction of reality in the society. By making use of paratexts to accentuate their own narratives and reject the opposing ones, the agents involved in the translation process show the undeniable role of paratexts in reframing and ideologically positioning the readers before and during their reading journey.

This study demonstrates that paratextual authorship is clearly a discursive practice. Therefore, it provides a rich and privileged observation point from which to discover the institutional basis of the discursive practices that frame translation. It is exactly at this point that translation studies can feed into other disciplines, such as political science. Regarding the paratexts studied here, they offer valuable insights into the Iranian institutional and ideological narratives about the Iran-Iraq war. Furthermore, the study shows how "paratextual authorship," by its very nature, creates difference. This difference is clearly evident in the results of this study, which demonstrate that paratextual authorship is a process fraught with clashes and tensions. This study shows the political import of paratexts in justifying domestic narratives about the war and in providing a means of contesting the Western narratives on the subject.

\section{NOTES}

1. مركز اسناد دفاع مقدس (Markaze-asnade defae moghaddas) [Center of documentation for Holy Defence].

2. جنگ تحمبلى (Jange tahmili) [war imposed].

3. دفاع مقدس (Defae moghaddas) [Defence Holy].

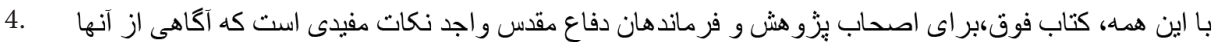

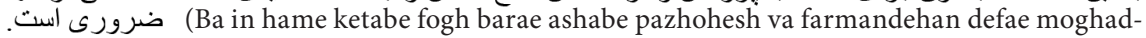
das vajede nokate mofidi ast ke aghahi az anha zarori ast) [This book contains many useful points for the researchers and commanders of the war that is necessary for them to be aware of]. 
5. See Appendix 1 for the references to the source texts under study.

6. See Note 1.

7. ش شهادت (shahadat) [morale of martyrdom].

8. فداكارى ها (fadakariha) [sacrifices].

9. Persian excerpts are translated by the authors.

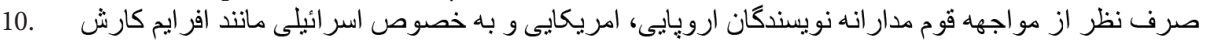

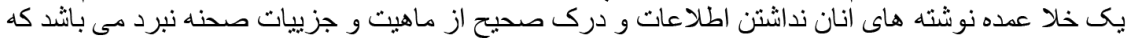

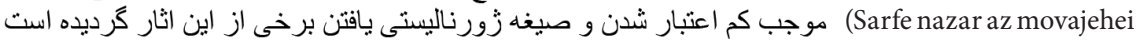
ghommadarane nevisandeghane oropaii, amricaii va be khosos esraiili manande Efraim karsh yek khalei omdeh neveshtetai anan nedashtane ettelaate va darke sahih az mahiyyat va joziiate sahnei nabard mibashad) [Regardless of the ethnocentric perspective of European, American, and especially Israeli writers, one shortcoming in their texts is that their incomplete knowledge and lack of understanding of the details and nature of the war zone].

11. مغايرت برخى مطالب كتاب با واقعيات تاريخ و نيز برخى كاستى هأ و غرض ورزى ها (Moghayerate barkhi matalebe ketab ba vagheyyate tarikh va barkhi kastiha va gharazvarziha) [contrary of the narratives with the historical facts and incompleteness and biased narratives].

12. در منن و بُ ذويس در داخل كيومه نوضديحاتى داده شده است (dar matn va panevis dar dakhele giome tozihati dadae shodeh ast) [in the text and the footnotes some explanations are added].

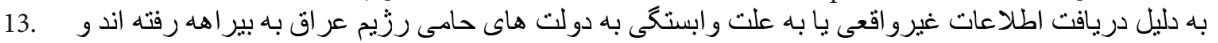
(be dalile daryafte ettelaate ghirevagheii ya be ellate vabasteghi be dolathaii hamiee regime iraq be birahe raftehand va ya be tahrife vagheiyyat ardakhteand) [these experts went astray because they received false information or they were affiliated with the countries supported Iraq, or they manipulated the facts].

14. در اسناد تاريخى كم ترين اثرى از نامى غير از خليج فارس براى اين مذطقه يافت نشده است (Dar asnade tarikhi kamtarin asari az nami gier az khlije fars bari in mantaghe peyda neshodeh ast) [In historical documents no trace is found of a name other than Persian gulf for this region].

15. خليج فارس (khalije fars) [Gulf Persian].

16. فرار (farar) [flight].

17. بروج (khorooj) [departure].

18. در كتاب بكاركيرى جنع افزارهاى شيميايى به دست ارتش عراق بيان شده است خروج (Dar ketab bekargirie jangafzarhae shimiaee be daste artesh araq bayan shodeh ast) [In the book the use of chemical weapons by the Iraqi army is mentioned].

19. (Dar labelae sotore ketab mitavan naghshe iyalate mottahede amrica ra dar tahrike Iraqva tahmile jang be iran moshahedeh kard) [In this book the role of the United States of America in stimulating Iraq and imposing the war on Iran is mentioned].

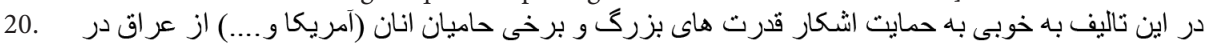

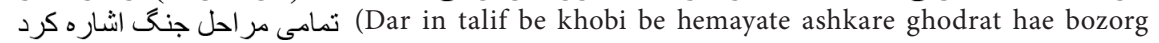
(amrica va ...) az Iraq dar tamamie marahele jang eshareh kard) [In this book, the support of Iraq by the USA in all the phases of the war has been mentioned].

21. جنغ از نگاه ديخران (jang az neghahe digharan) [war from others' perspective].

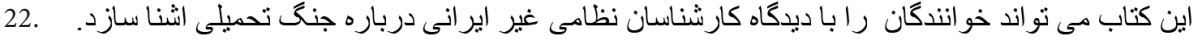
(enteshare in ketab dar iran mitavand khannadeghan ra be didghahae karshenasane nezami dabare jange tahmili ashena sazad. Tabii ast ke fahme behtare vaghae va tahavvolate jange tahmili niaz be mottale an az didghahei mokhtalef darad) [This book can familiarize the readers with the ideas of foreign military experts on the imposed war. Better understanding of the events and developments of the war requires its investigation from different perspectives].

\section{REFERENCES}

Al-Herthani, Mahmud Mohamad (2009): Edward Said in Arabic: Narrativity and Paratextual Framing. Doctoral dissertation, unpublished. Manchester: University of Manchester.

Ayoub, Amai (2010): Framing Translated and Adapted Children's Literature in the Kilani Project:

A Narrative Perspective. Doctoral dissertation, unpublished. Cairo: University of Helwan. BAKer, Mona (2006): Translation and Conflict: A Narrative Account. London/New York: Routledge. 
BALDO, Michela (2008): Translation as Re-Narration in Italian-Canadian Writing: Codeswitching, Focalization, Voice and Plot in Nino Ricci's Trilogy and its Italian Translation. Doctoral dissertation, unpublished. Manchester: University of Manchester.

BRISSET, Annie (1990/1996): A Sociocritique of Translation: Theatre and Alterity in Québec, 1968-1988. (Translated from French by Rosalind Gill and Roger Gannon). Toronto: University of Toronto Press.

Chubin, Shahram and Tripp, Charles (1988): Iran and Iraq at War. London: I.B. Tauris.

Donovan, Jerome (2011): The Iran-Iraq War: Antecedents and Conflict Escalation. London/New York: Routledge.

Dubbati, Barkuzar and Abudayed, Haneen (2017): The Translator as an Activist: Reframing Conflict in the Arabic Translation of Sacco's Footnotes in Gaza. The Translator. 23(1):1-19.

Genette, Gerard (1987/1997): Paratexts: Thresholds of Interpretation. (Translated from French by Jane E. Lewin) Cambridge: Cambridge University Press.

Gil Bardaji, Anna, Orero, Pilar, and Rovira-Esteva, Sara, eds. (2012): Translation Peripheries: Paratextual Elements in Translation. Bern: Peter Lang.

Gil Bardaji, Anna (2009): Traducir al andalus: el discurso del otro en el arabismo espanol. Lewiston/New York/Lampeter: Edvin Meller Press.

Harding, Sue-Ann (2009): News as Narrative: Reporting and Translating the 2004 Beslan Hostage Disaster. Doctoral dissertation, unpublished: Manchester: University of Manchester.

HARDING, Sue-Ann (2012): Beslan: six stories of the siege. Manchester: University of Manchester.

Harvey, Keith (2003): 'Events' and 'Horizons.' Reading Ideology in the 'Bindings' of Translations. In: María Calzada PÉRez, ed. Apropos of Ideology. Translation Studies on IdeologyIdeologies in Translation Studies. Manchester: St. Jerome, 43-70.

Hijo, Nael and Kaur, Surinderpal (2017): The Paratextual Analysis of English Translations of Arabic Media Narratives on Daesh. The Southeast Asian Journal of English Language Studies. 23(3):21-36.

Hiltermann, Joost. R. (2007): A poisonous affair: America, Iraq, and the Gassing of Halabja. Cambridge/New York: Cambridge University Press.

Hooton, Edward. R, Cooper, Tom, and Nadimi, Farzin (2016): The Iran-Iraq War. Solihull: Helion \& Company.

KIM, Kyung Hye (2017): Reframing the victims of WWII Through Translation. Target. 29(1):87109.

Kovala, Urpo (1996): Translations, Paratextual Mediation, and Ideological Closure. Target. 8(1):119-147.

Meretoja, Hanna (2014): Narrative and Human Existence: Ontology, Epistemology, and Ethics. New Literary History. 45(1):89-109.

Mink, Louis (1970): History and Fiction as Modes of Comprehension. New Literary History. 1(3):541-558.

Murray, Williamson and Woods, Kevin (2014): The Iran-Iraq War: A Military and Strategic History. Cambridge: Cambridge University Press.

Roberts, Deborah (2010): Reading Antigone in Translation: Text, Paratext, Intertext. In: Stephen E. Wilmer and Audrone Zukanskaite, eds. Interrogating Antigone in Postmodern Philosophy and Criticism. Oxford: Oxford University Press, 283-312.

Somers, Margaret (1997): Deconstructing and Reconstructing Class Formation Theory: Narrativity, Relational Analysis, and Social Theory. In: John R. HALL, ed. Reworking Class. Ithaca/London: Cornell University Press, 73-105.

Somers, Margaret and Gibson, Gloria (1994): Reclaiming the Epistemological "Other": Narrative and the Social Constitution of Identity. In: Craig Calhoun, ed. Social Theory and the Politics of Identity. Oxford/Cambridge: Blackwell, 37-99.

Summers, Caroline (2013): Narratives of Dissidence and Complicity: Translating Christa Wolf before and after the Fall of the Wall. Doctoral dissertation, unpublished. Manchester: University of Manchester. 
TAhir GürÇAĞLAR, Şehnaz (2002): What texts don't tell: The uses of paratexts in translation research. In: Theo Hermans, ed. Cross-cultural transgressions. Manchester: St. Jerome, 44-60.

Watts, Richard (2000): Translating Culture: Reading the Paratexts of Aime Cesaire's Cahier d'un retour au pays natal. TTR. 13(2):29-46.

\section{APPENDICES}

Appendix 1: References for the corpus under study

Cordesman, Anthony and Wagner, Abraham (1990): The Lessons of Modern War. Vol. 2. The Iran-Iraq War. London: Westview Press.

Cordesman, Anthony and WAgner, Abraham (1990/2011): درس هاى جنى مدرن: جنع ايران و عراق (Darshaye jang-e- modern: jang-e- Iran va Iraq) [Modern Warfare Lessons: The Iran-Iraq War]. (Translated from English by Hussein YeKTA) Tehran: Marzoboom.

Hiltermann, Joost R. (2007): A poisonous affair: America, Iraq, and the Gassing of Halabja. Cambridge/New York: Cambridge University Press.

Hiltermann, Joost R. (2007/2013): رابطه زهرآكين: آمريكا-عراق و بمباران شيميايى حلبجه (Rabeteye zahraghin: America, Iraq va bombarane shimiaii Halabjeh) [Poisonous relationship: USIraq and Halabja's chemical bombardment]. (Translated from English by Yaghoob NeMATI) Tehran: Marzoboom.

Hiro, Dilip (1991): The Longest War: The Iran-Iraq Military Conflict. London/New York: Routledge.

Hiro, Dilip (1991/2011): طولانى ترين جنگ: رويارويى نظامى ايران و عراق (Tulanitarin jang: ruyaruii nezamie Iran va Iraq) [The longest war: the military confrontation between Iran and Iraq]. (Translated from English by Alireza FARshCHI, Reza FARIDZAhed, and Saeed KAFI) Tehran: Marzoboom (Affiliated with the Holy Defence Documentation Center).

Joyner, Christopher C. (1990): The Persian Gulf War: Lessons for Strategy, Law, and Diplomacy. New York: Greenwood Press.

Joyner, Christopher C. (1990/2011): درس هايى از راهبرد، حقوق و ديبلماسى در جنى ايران و عراق (Darshaii az rahbord, hoghogh va diplomacy dar jang-e- Iran va Iraq) [Lessons from Strategy, Law and Diplomacy in the Iran-Iraq War]. (Translated from English by Davood OlamaiI) Tehran: Marzoboom.

KING, Ralph and KARsH, Efraim (2006): The Iran-Iraq War and the First Gulf War. London/New York: Routledge.

KING, Ralph and KARsh, Efraim (2006/2008): جنى ابران و عراق: بِيامد هاى سياسى- تحليل نظامى) (Jang-e-Iran va Iraq: payamadhaye siasi- tahli-e nezami) [Iran-Iraq War: Political Consequences - Military Analysis]. (Translated from English by Sayed Saadat HosseIni Damabi) Tehran: The Holy Defence Documentation Center.

Navias, Martin S. and Ноотоn, Edward R. (1996): Tankers War: The Assault on Merchant Shipping during the Iran-Iraq War. London: I.B. Tauris.

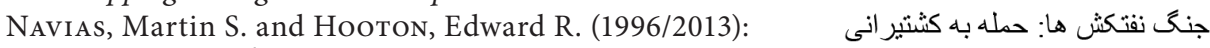
تجارى در جنى ايران و عراق (Jang-e- naftkeshha: hamle be keshtiranie tejari dar jang-eIran va Iraq) [Tanker Wars: Attack on Commercial Shipping in the Iran-Iraq War]. (Translated from English by Pejman Poorajbari and Rahmat Ghareh) Tehran: The Fountain for the Preservation of Works and Values of the Holy War.

\section{Appendix 2: References for the paratexts of the translations under study}

Holy Defence Documentation Center (2008): مقدمه (Moghaddameh) [Preface]. In: Ralph KIng and Efraim KARsh. جنى ايران و عراق: بيامد هاى سياسي- تحليل نظامى (Jang-e-Iran va Iraq: payamadhaye siasi- tahli-e nezami) [Iran-Iraq War: Political Consequences - Military Analysis]. (Translated from English by Sayed Saadat Hosseini Damabi) Tehran: Holy Defence Documentation Center, 11-21. 
Holy Defence Documentation Center (2011a): مقدمه (Moghaddameh) [Preface]. In: Anthony Cordesman and Abraham WAgner. درس هاى جنى مدرن: جنح ايران و عراق (Darshaye jange- modern: jang-e- Iran va Iraq) [Modern Warfare Lessons: The Iran-Iraq War]. (Translated from English by Hussein YeкTA) Tehran: Marzoboom, 15-36.

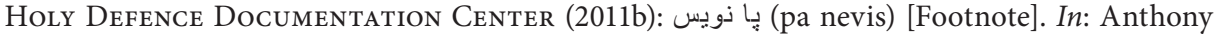
Cordesman and Abraham WAgner. درس هاى جنى مدرن: جنى ايران و عراق (Darshaye jange- modern: jang-e- Iran va Iraq) [Modern Warfare Lessons: The Iran-Iraq War]. (Translated from English by Hussein YeкTA) Tehran: Marzoboom, 40, 56.

Holy Defence Documentation Center (2011c): مقدمة (Moghaddameh) [Preface]. In: Dilip Hiro. طولانى ترين جنى: رويارويى نظامى ايران و عراق (Tulanitarin jang: ruyaruii nezamie Iran va Iraq) [The longest war: the military confrontation between Iran and Iraq]. (Translated from English by Alireza Farshchi, Reza Faridzahed, and Saeed Kafi) Tehran: Marzoboom (Affiliated with the Holy Defence Documentation Center), 7-12.

Holy Defence Documentation Center (2011d): بֶ نويس (pa nevis) [Footnote]. In: Dilip Hiro. طولانى ترين جنگ: رويارويى نظامى ايران و عراق (Tulanitarin jang: ruyaruii nezamie Iran va Iraq) [The longest war: the military confrontation between Iran and Iraq]. (Translated from English by Alireza Farshchi, Reza Faridzahed, and Saeed Kafi) Tehran: Marzoboom (Affiliated with the Holy Defence Documentation Center), 162.

Holy Defence Documentation Center (2011e): مقدمه (Moghaddameh) [Preface]. In: Christopher C. Joyner. درس هايى از راهبرد، حقوق و ديِلماسى در جنى ايران و عراق (Darshaii az rahbord, hoghogh va diplomacy dar jang-e- Iran va Iraq) [Lessons from Strategy, Law and Diplomacy in the Iran-Iraq War]. (Translated from English by Davood OlamaII) Tehran: Marzoboom, 13-19.

Holy Defence Documentation Center (2011f): بطا ذويس (pa nevis) [Footnote]. In: Christopher C. Joyner. درس هايى از راهبرد، حقوق و ديبِلماسى در جنى ايران و عراق (Darshaii az rahbord, hoghogh va diplomacy dar jang-e- Iran va Iraq) [Lessons from Strategy, Law and Diplomacy in the Iran-Iraq War]. (Translated from English by Davood OlamaII) Tehran: Marzoboom, $25,149$.

Holy Defence Documentation Center (2013a): با ذو ذويس (pa nevis) [Footnote]. In: Joost R. HiltermanN, Joost. رابطه زهرآكين: آمريكا_عراق و بمباران شيميايى حلبه (Rabeteye zahraghin: America, Iraq va bombarane shimiaii Halabjeh) [Poisonous relationship: US-Iraq and Halabja's chemical bombardment]. (Translated from English by Yaghoob Nemati) Tehran: Marzoboom, 92, 186.

Holy Defence Documentation Center (2013b): مقدم عراق (Moghaddameh) [Preface]. In: Martin

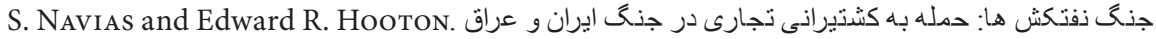
(Jang-e- naftkeshha: hamle be keshtiranie tejari dar jang-e- Iran va Iraq) [Tanker Wars: Attack on Commercial Shipping in the Iran-Iraq War]. (Translated from English by Pejman Poorjabari and Rahmat Ghareh) Tehran: The Foundation for the Preservation of Works and Values of the Holy War, 9-16.

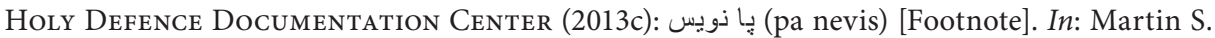

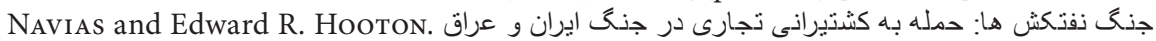
(Jang-e- naftkeshha: hamle be keshtiranie tejari dar jang-e- Iran va Iraq) [Tanker Wars: Attack on Commercial Shipping in the Iran-Iraq War]. (Translated from English by Pejman PoorJabari and Rahmat Ghareh) Tehran: The Foundation for the Preservation of Works and Values of the Holy War, 144. 
124 MetA, LXIV, 1, 2019

Appendix 3: Original Persian references for the translations under study

علمايى، داوود ( •وسا): درس هايى از راهبرد حقوق دييلماسى در جنغ ايران و عراق. تهران: نشر مرزو بوم. ( وابسته به مركز اسناد دفاع مقدس).

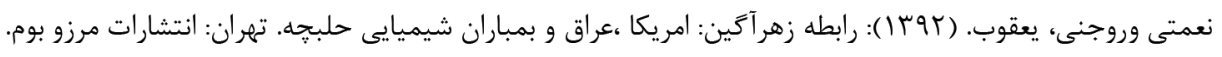

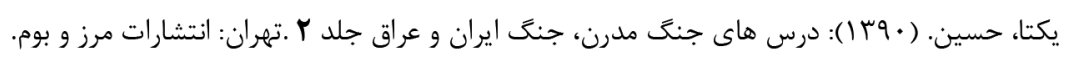

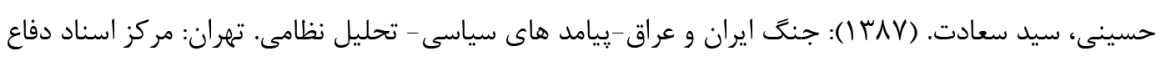
مقدس.

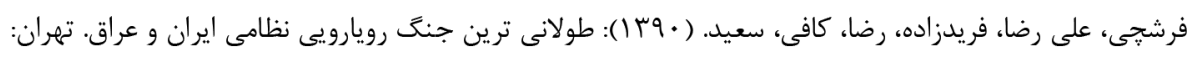
نشر مرزو بوم.

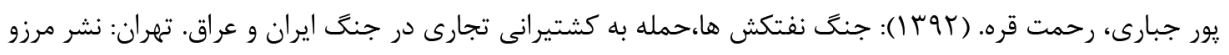

